\title{
Fundic gland polyps and duodenal gastric heterotopia - is this an unusual association?
}

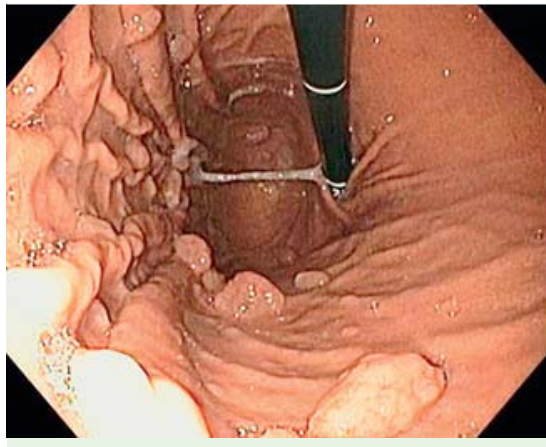

Fig. 1 Esophagogastroduodenoscopy showing multiple small, sessile polyps in the fundus and upper body of the stomach in a 72-yearold woman on proton pump inhibitor therapy for more than 10 years.

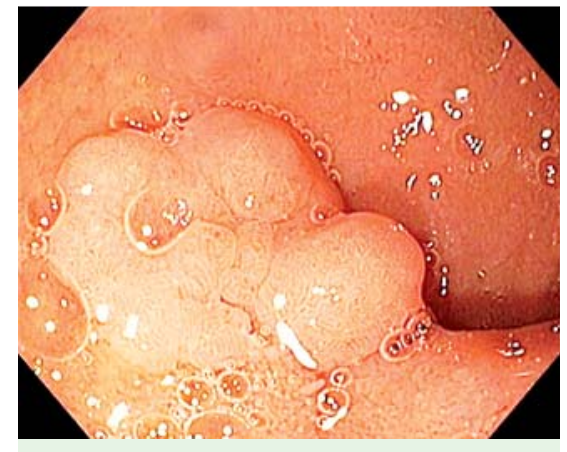

Fig. 2 Polypoid sessile lesion in the duodenal bulb.
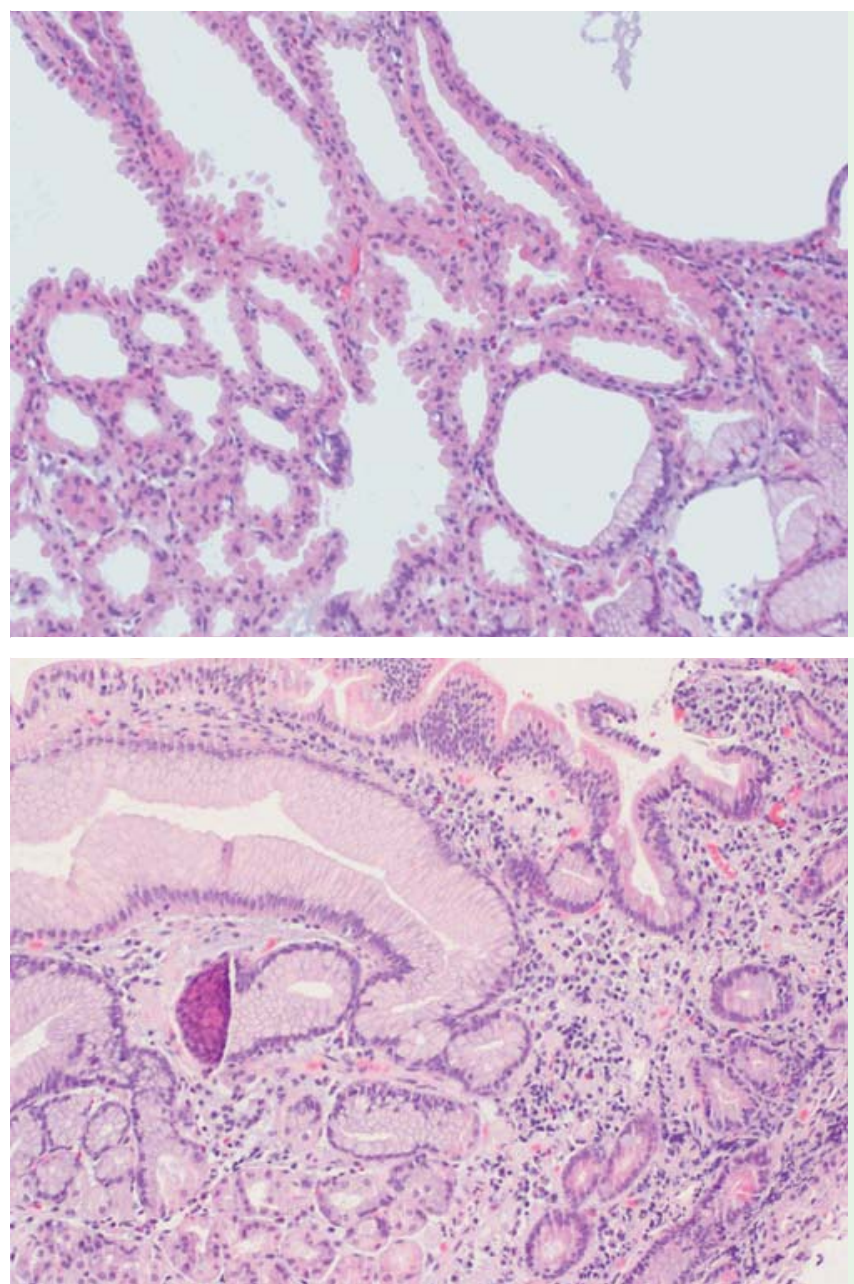

Fig. 3 Histology of the gastric polyps: cystically dilated glands lined by normal cell types of the oxyntic mucosa (hematoxylin and eosin, $\times 10$ ).

Fig. 4 Histology of the duodenal lesion: intestinal mucosa (upper right), foveolar mucosa (upper left), and crypts of the fundic type (below) (hematoxylin and eosin, $\times 10)$. 


\section{Rita Barosa', Pedro Pinto-Marques ${ }^{1,2}$, Raquel Ilgenfritz ${ }^{2}$}

${ }^{1}$ Department of Gastroenterology, Hospital Garcia de Orta, Almada, Portugal

${ }^{2}$ Department of Gastroenterology, Hospital da Luz, Lisbon, Portugal

\section{References}

1 Shaib YH, Rugge M, Graham DY et al. Management of gastric polyps: an endoscopybased approach. Clin Gastroenterol Hepatol 2013; 11: 1374-1384

2 Genta RM, Kinsey RS, Singhal A et al. Gastric foveolar metaplasia and gastric heterotopia in the duodenum: no evidence of an etiologic role for Helicobacter pylori. Hum Pathol 2010; 41: 1593-1600

3 Conlon N, Logan E, Veerappan S et al. Duodenal gastric heterotopia: further evidence of an association with fundic gland polyps. Hum Pathol 2013; 44: 636-642

\section{Bibliography}

Dol http://dx.doi.org/

10.1055/s-0034-1393390

Endoscopy 2015; 47: E561-E562

(c) Georg Thieme Verlag KG

Stuttgart · New York

ISSN 0013-726X

\section{Corresponding author}

\section{Rita Barosa, MD}

Department of Gastroenterology Hospital Garcia de Orta

Avenida Torrado da Silva, 2801-951

Almada

Portugal

Fax: +351-212-957-004

a.rita.b@gmail.com 